\title{
A Review of Ethiopia's Security Challenges in The Horn of Africa
}

\author{
by \\ Colonel Goitom Farus Belay \\ Ministry of National Defense, Ethiopia
}
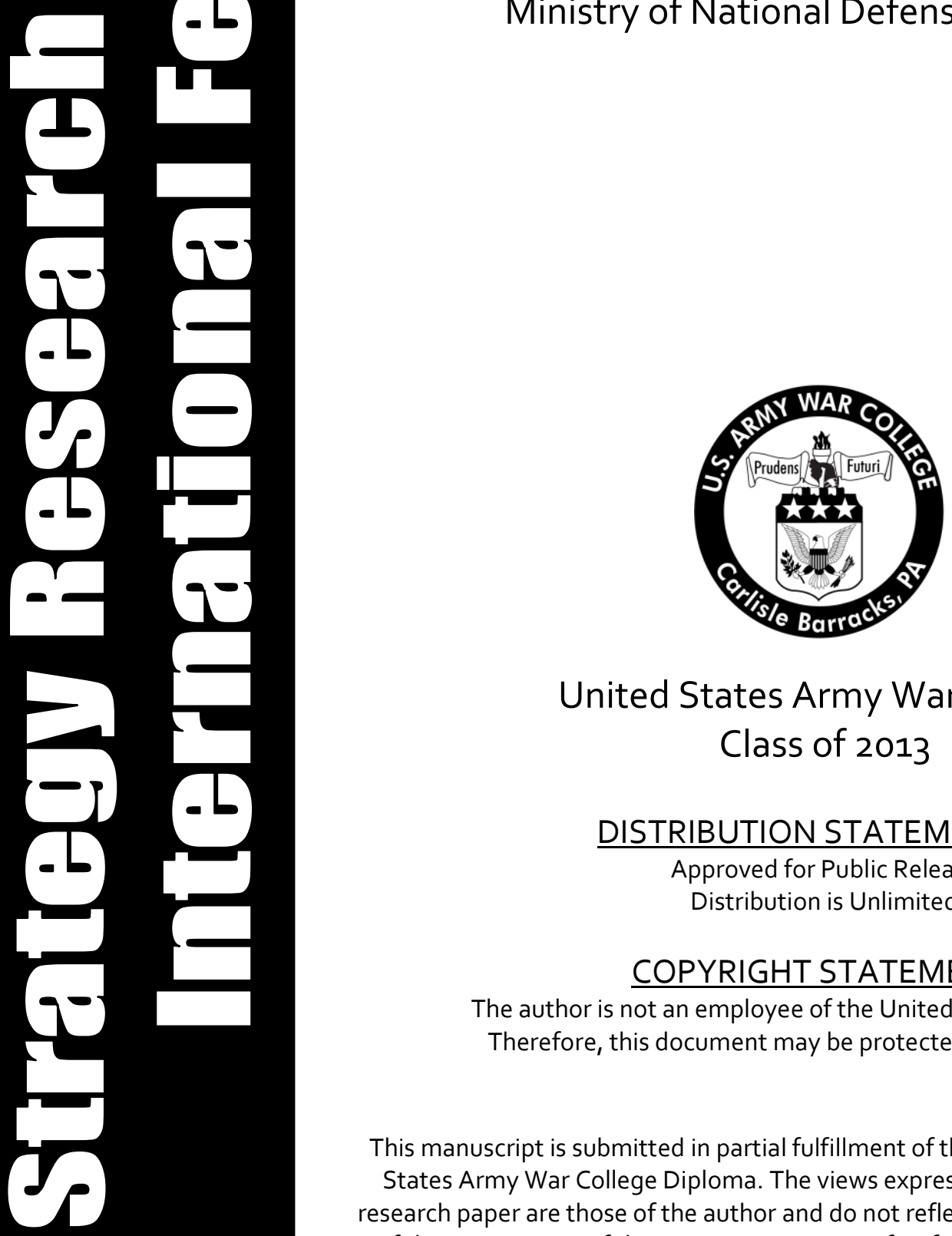

United States Army War College Class of 2013

\section{DISTRIBUTION STATEMENT: A}

Approved for Public Release

Distribution is Unlimited

\section{COPYRIGHT STATEMENT:}

The author is not an employee of the United States government.

Therefore, this document may be protected by copyright law.

This manuscript is submitted in partial fulfillment of the requirements of the United States Army War College Diploma. The views expressed in this student academic research paper are those of the author and do not reflect the official policy or position of the Department of the Army, Department of Defense, or the U.S. Government. 
The U.S. Army War College is accredited by the Commission on Higher Education of the Middle States Association of Colleges and Schools, 3624 Market Street, Philadelphia, PA 19104, (215) 662-5606. The Commission on Higher Education is an institutional accrediting agency recognized by the U.S. Secretary of Education and the Council for Higher Education Accreditation. 


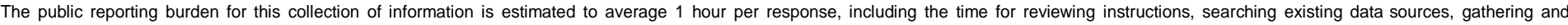

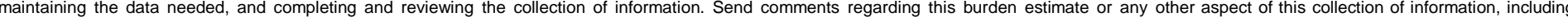

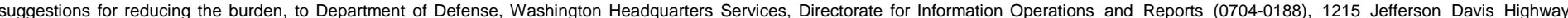

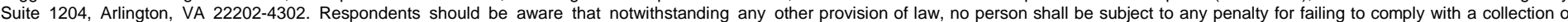
information if it does not display a currently valid OMB control number. PLEASE DO NOT RETURN YOUR FORM TO THE ABOVE ADDRESS.
1. REPORT DATE (DD-MM-YYYY)
2. REPORT TYPE
$\mathrm{XX}-03-2013$
STRATEGY RESEARCH PROJECT

4. TITLE AND SUBTITLE

A Review of Ethiopia's Security Challenges in The Horn of Africa

3. DATES COVERED (From - To)

5a. CONTRACT NUMBER

5b. GRANT NUMBER

5c. PROGRAM ELEMENT NUMBER

6. AUTHOR(S)

Colonel Goitom Farus Belay

Ministry of National Defense, Ethiopia

5d. PROJECT NUMBER

5e. TASK NUMBER

5f. WORK UNIT NUMBER

7. PERFORMING ORGANIZATION NAME(S) AND ADDRESS(ES)

Professor Perry Ball

8. PERFORMING ORGANIZATION REPORT NUMBER

Department of National Security and Strategy

9. SPONSORING/MONITORING AGENCY NAME(S) AND ADDRESS(ES)

U.S. Army War College

122 Forbes Avenue

Carlisle, PA 17013

10. SPONSOR/MONITOR'S ACRONYM(S)

11. SPONSOR/MONITOR'S REPORT NUMBER(S)

12. DISTRIBUTION / AVAILABILITY STATEMENT

Distribution A: Approved for Public Release. Distribution is Unlimited.

13. SUPPLEMENTARY NOTES

Word Count: 5026

\section{ABSTRACT}

The Ethiopian government determined that terrorism had become a security threat to the Horn of Africa following the collapse of Somalia's Said Barre government in 1991. The Al-ltihaad terrorist group began to attack Ethiopia in 1996. Somalia also became a safe-haven for Ethiopian terrorist groups and a corridor for proxy attacks against Ethiopia by regional adversaries like Eritrea. The Ethiopian government has responded to these threats by undertaking multiple initiatives including security and training assistance for the TGF, support for the African Mission in Somalia (AMISOM), and security cooperation with the U.S. government. This paper will discuss the security challenges and initiatives confronting Ethiopia in its fight against terrorism in the Horn of Africa and provide recommendations for future courses of action.

\section{SUBJECT TERMS}

National Security, Insurgency, Terrorism

\begin{tabular}{|c|c|c|c|c|c|}
\hline 16. SECURI & CLASSIFICATIC & & 17. LIMITATION & 18. NUMBER OF PAGES & 19a. NAME OF RESPONSIBLE PERSON \\
\hline $\begin{array}{l}\text { a. REPORT } \\
\text { UU }\end{array}$ & $\begin{array}{c}\text { b. ABSTRACT } \\
\text { UU }\end{array}$ & $\begin{array}{l}\text { c. THIS PAGE } \\
\text { UU }\end{array}$ & UU & 30 & $\begin{array}{l}\text { 19b. TELEPHONE NUMBER (Include area } \\
\text { code) }\end{array}$ \\
\hline
\end{tabular}



USAWC STRATEGY RESEARCH PROJECT

\section{A Review of Ethiopia's Security Challenges in The Horn of Africa}

by

Colonel Goitom Farus Belay

Ministry of National Defense, Ethiopia

Professor Perry Ball

Department of National Security and Strategy

Project Adviser

This manuscript is submitted in partial fulfillment of the requirements of the United States Army War College Diploma. The U.S. Army War College is accredited by the Commission on Higher Education of the Middle States Association of Colleges and Schools, 3624 Market Street, Philadelphia, PA 19104, (215) 662-5606. The Commission on Higher Education is an institutional accrediting agency recognized by the U.S. Secretary of Education and the Council for Higher Education Accreditation.

The views expressed in this student academic research paper are those of the author and do not reflect the official policy or position of the Department of the Army, Department of Defense, or the U.S. Government. 



\begin{tabular}{ll} 
& \multicolumn{1}{c}{ Abstract } \\
Title: & A Review of Ethiopia's Security Challenges in The Horn of Africa \\
Report Date: & March 2013 \\
Page Count: & 30 \\
Word Count: & 5026 \\
Key Terms: & National Security, Insurgency, Terrorism \\
Classification: & Unclassified
\end{tabular}

The Ethiopian government determined that terrorism had become a security threat to the Horn of Africa following the collapse of Somalia's Said Barre government in 1991. The Al-Itihaad terrorist group began to attack Ethiopia in 1996. Somalia also became a safe-haven for Ethiopian terrorist groups and a corridor for proxy attacks against Ethiopia by regional adversaries like Eritrea. The Ethiopian government has responded to these threats by undertaking multiple initiatives including security and training assistance for the TGF, support for the African Mission in Somalia (AMISOM), and security cooperation with the U.S. government. This paper will discuss the security challenges and initiatives confronting Ethiopia in its fight against terrorism in the Horn of Africa and provide recommendations for future courses of action. 



\section{A Review of Ethiopia's Security Challenges in The Horn of Africa}

The Horn of Africa has been unstable for more than two decades following the fall of Somalia's central government in 1991. Consequently, Somalia has become safe haven for the proliferation of internal and external terrorist groups. Ethiopia has been affected by the terrorism perpetrated by Somalia-based terrorist groups. One of the groups, Al-Ittihad Al-Islamiya (AIAI), and its indigenous terrorist group affiliate, the Ogaden National Liberation Front (ONLF), attacked Ethiopia several times between 1995 and 1997. These groups carried out bombings of bars, hotels and public buildings in both Addis Ababa and other towns in eastern Ethiopia. AIAI also attacked Ethiopian defense force units in the Ethiopian border town of Dollo Ado during the same period. The Somalia-based terrorist threat to Ethiopia reached a peak in 2006 when another group, the Eritrean-backed Islamic Court Union (ICU), declared a Jihad on Ethiopia. Ethiopia also faces cross-border security challenges posed illegal trade, proliferation of small arms, and human trafficking.

Ethiopia regards Somalia not only as a neighboring country but also as a brotherly African country. Ethiopia admits tens of thousands of Somali refugees annually. Ethiopia's current military intervention in Somalia is a demonstration of its commitment to regional stability and not a continuation of the hitherto hostile relationship between both countries as some observers have alleged. Somalia has the primary responsibility of addressing insecurity within its borders, but the country's capacity to deal with the current security challenges has been weakened by the protracted conflict amongst its various internal groups and the political, social, and economic instability that conflict has produced. 
Therefore, the international community, African Union (AU), and neighboring states have essential roles to play in bringing stability to Somalia and the Horn of Africa in general. Ethiopia played a major role in the establishment and sustenance of the Somalia Transitional Federal Government (TFG) in 2004. Ethiopia's military intervention in 2006 also provided the conditions for the TFG to relocate from Nairobi, Kenya to Baidoa, in south central Somalia, and later to Mogadishu, the capital city Somalia. The Ethiopian government continues to provide political and diplomatic support to the TFG and training assistance to the TFG security forces.

Ethiopia's current initiatives to combat terrorism in the Horn of Africa focus on integrating and reinforcing the regional military efforts and cooperation of the $A U$, Intergovernmental Authority for Development (IGAD) member countries, and the United States to eliminate the Al-Shabaab terrorist group operating in Somalia. This is important for Ethiopia because sustainable peace and security in Somalia will have a positive impact on Ethiopia and the Horn of Africa as a whole. Ethiopia remains committed to providing the necessary security assistance to the TFG and its security forces and other collaborative efforts in support of the African Union Mission in Somalia (AMISOM). However, Somalia is still far from its goals of building a strong central government and defeating terrorism, despite recent positive developments in the country. 
The Historical Relationship between Ethiopia and Somalia Ethiopia shares a common boundary with six countries: Djibouti, Eritrea, Kenya, Somalia, South Sudan, and the Sudan. The border with Somalia is about 1,000 miles long. Ethiopia and Somalia had a history of war and hostile relations even before the emergence of terrorist groups in Somalia. This was partly the result of colonial legacies, but mainly because of previous Somali efforts to create a greater Somalia at the expense of its neighbors, including Ethiopia. For example, Somalia forces invaded the Ethiopian Ogaden region in mid-1977, but they were repulsed by Ethiopians with Soviet and Cuba assistance in the following year.

Gebru Tareke, emeritus professor of history at Hobart and Smith College, asserts that Somalia invaded Ethiopia in 1977 to achieve a dream "that had eluded its leaders for 17 years: the annexation Ogaden, a first step towards the creation of a greater Somalia co-extensive with the Somali people in the Horn of Africa."1 The failed expansionist policy of Somali rulers had brought nothing to Somalia, but hostility and conflicts with all its neighbors, especially Ethiopia. Moreover, Somalia had often allied with groups and countries it believed were anti-Ethiopian and had thereby disturbed Ethiopia's peace. ${ }^{2}$ Gebru Tareke also illustrated that Somalia had continued supporting indigenous rebel groups such as Western Somalia Liberation Front (WSLF) and SomaliAbo Liberation Front (SALF) to achieve its ambition of creating a greater Somalia. "Ethiopians won the war but not the peace. Skirmishes with the defeated but stubborn Somalis who still contested a large piece of Ethiopian territory continued for another three years"3 
However, previous Ethiopian governments, particularly the Derge regime, followed an adversarial and oppressive domestic and foreign policy to distract the Ethiopian people from domestic problems and which inflamed the hostile relationship between the two countries. In this regard, Ethiopia's security policy and strategy posits that:

Ethiopia, for its part, rather than responding to the threat by respecting the right of Ethiopian Somalis and by fostering brotherhood between the peoples of Ethiopia, so Ethiopian Somalis could live in voluntary unity with their other fellow Ethiopians, resorted to dismantling Somalia to the extent possible. The policy was to respond to Somali aggression by taking the war to Somalia and, along the way, aggravating the contradiction between the Somali clans. ${ }^{4}$

Ethiopia's security challenges related to the old dream of a greater Somalia seemed to come to an end as a consequence of the collapse of Said Barre government in Somalia. However, the absence of a central government in Somalia contributed to a new security dynamic associated with the rise of Islamic fundamentalism and terrorist groups such as Al-Attihad al-Islamia (AIAI) and the Islamic Courts Union (ICU) in Somalia. As a result, these terrorist groups have become an even greater threat to the Horn of Africa and Western interests.

Angel Rabasa, a senior political scientist at the RAND Corporation, believes that the emergence of terrorist groups in the Horn of Africa in recent decades is linked to "the spread of Salafi and Wahhabi ideologies, which has put pressure on traditional and Sufi Practices, and in the emergence of extremists and terrorist group influenced by these ideologies." Rabasa also elaborated that "all of these developments originated outside East Africa, but they had strong reverberations in East Africa because of the region's geographical and cultural proximity to the Middle East." 6 
Another factor that contributed to the emergence of terrorist groups in the Horn of Africa was the withdrawal of the Soviet Union from Afghanistan in 1989. An estimated 25,000 foreign jihadists returned home where they fostered radical Islamic movements in many Muslim countries, including Somalia. ${ }^{7}$ The flow and strength of terrorist groups has been intensified mainly due to the legitimacy of Jihad in Afghanistan and the strong connection of expatriate mujahadin jihadists to Al-Qaeda. ${ }^{8}$ Several hundred Afghan jihadist veterans, who were expelled from Pakistan in 1993, also joined the Somali jihadists after passing through Sudan. ${ }^{9}$

Ethiopia's National Security Challenges and Somalia-based Terrorism The term terrorism has been defined in various ways. This is mainly because of the complex, political and subjective nature of the term and the act. Some define terrorism from a legal or psychological perspective; others defined it from a political or security perspective. Although there are many definitions given for terrorism, the main characteristic that is generally agreed upon is that terrorism involves violence and the threat of violence. Hence, the definition of a terrorist can be described as a militant or a militant group that has criminal intent and plans and acts violently against civilian targets for political and economic goals. ${ }^{10}$

Martha Crenshaw, a senior fellow at Center for International Security and Cooperation (CISC), and professor of political science by courtesy at Stanford University, for example, defines terrorism as "a conspiratorial style of violence calculated to alter the attitudes and behavior of multitude audiences. It targets the few in a way that claims the attention of the many. Terrorism is not mass or collective violence but rather the direct activity of small groups." 11 
A State's definition of terrorism, on the other hand, it is not always consistent with the academic's definition of terrorism. For instance, U.S. law defines terrorism as "premeditated, politically motivated violence against non-combatant targets by subnational groups or clandestine agents." ${ }^{12}$

The U.S. Department of Defense (DOD) has defined terrorism as "the calculated use of violence or the threat of violence against individuals or property, to inculcate fear, intended to coerce or to intimidate government or societies in the pursuit of goals that are political, ideology or religious."13 The Federal Democratic Republic of Ethiopia antiterrorism law (Proclamation No. 652/2009) defines terrorism as "whosoever or a group intending to advance a political, religious or ideological cause by coercing the government, intimidating the public or section of the public, or destabilizing or destroying the fundamental political, constitutional or, economic or social institution of the country." ${ }^{14}$

The challenge of finding a common definition of terrorism will continue. Terrorism has a long history in Africa, particularly in the Horn of Africa which has experienced terrorist attacks since before the 9/11 attack in the U.S. Over the past decade, a significant number of terrorist attacks and operations have taken place in Africa, both north and south of the Sahara. ${ }^{15}$ For over a decade, the United States has considered the Horn of Africa a major source of global terrorism. The terrorist bombing of American embassies in Nairobi, Kenya, and Dar es Salaam, Tanzania in 1998 killed over 200 people and injured more than $4,000{ }^{16}$ These terrorist attacks and the presence of terrorist groups in Somalia evoked the attention of the United States and the Horn countries. 
Former U.S. Ambassador to Ethiopia David H. Shinn, described the Horn of Africa as "the backdoor to the troubled Persian Gulf, the source of much of today's international terrorism." ${ }^{17}$

The Somalia-based terrorist groups targeted Ethiopia even before the 1998 terrorist attacks in Nairobi and Dar es Salaam. Terrorist acts that have occurred since the current Ethiopian government took power in 1991 have usually been bombings of hotels, restaurants, government buildings, and public means transportation, and assassination attempts. The most critical incident occurred when Egyptian terrorists associated with the Al- Gamaa Al-Islamya Islamic group attempted to assassinate President Hosni Mubarak in Addis Ababa in 1999. ${ }^{18}$

Furthermore, Ethiopia has continued to be a target of terrorist groups based in Somalia. Somalia continues as a main operating base not only for Somali terrorists, but also serves as a base for indigenous terrorist groups such as the Ogaden National Liberation Front (ONLF) and others. Consequently, these terrorist groups have attacked Ethiopia several times and most importantly, they have tried to undermine EthiopiaSomalia border security by conducting various terrorist activities. For instance, the ONLF killed more than 70 Ethiopians and Chinese oil project workers in 2007. This terrorist group has also conducted several other attacks in Ethiopia, killing civilians and local and regional authorities. For example, they attempted to assassinate the former Federal Transportation Minister and former head of the Ethiopian Somali regional government at Addis Ababa and Jigjiga, respectively.

Ethiopia's Somali region is one of the most poverty-prone areas in Ethiopia. The Federal Government of Ethiopia and the Somali Regional Government have been 
making substantial efforts to enhance peace, security, development, and good governance in the region. In contrast, the ONLF has conducted destructive activities, such as terrorizing the local population and destroying public services, primarily to damage Ethiopia's image in the eyes of the international community. As a result, the region remains vulnerable and highly impacted by the lawlessness of Somalia and the poor governance, poverty, and insecurity across the region which is aggravated by the actions of these terrorist groups.

Ethiopia's security challenges became more serious and complex when the Eritrean government began to back Somalia-based terrorist groups and Jihadists. The Eritrean government has made persistent efforts to strengthen these terrorist groups by providing assistance such as training in Eritrea and Somalia and various types of weapons. The Eritrean government also continues a propaganda campaign against Ethiopia and the international community efforts to stabilize Somalia. The AU, IGAD and the international community have expressed concern and have asked Eritrea to stop sponsoring the Somali terrorist organizations. The Eritrean government continues to provide this support despite multiple regional and international attempts to persuade it to refrain from its destructive role towards the peace and security of the region.

The U.N. Security Council (UNSC) placed additional sanctions on Eritrea on December 5,2011 , because of its failure to responds to these requests. The related UNSC resolution states, "Eritrea has continued to provide political, financial, training and logistical support to armed opposition groups, including Al-Shabaab, engaged in undermining peace, security and stability in Somalia and the region." ${ }^{19}$ 
According to the U.N. Observers' report of November 2006, Eritrea's involvement in Somalia is among the worst. The Eritrean government allegedly provided the ICU at least 28 separate consignments of arms, ammunition and military equipment. Eritrean military officers and troops have assisted the ICU by providing not just weapons and training, but also political assistance..$^{20}$ Eritrea's decision and appetite to continue sponsoring the fundamentalist Islamic terrorists groups in Somalia and Ethiopia is associated with their intention to create another war front and coalition against Ethiopia. Roland Marchal, a senior research fellow at the National Center of Scientific Research, Paris, stated that:

Eritrea's clandestine involvement and support to the Islamic Extremists and separatist terrorists of the Horn of Africa sub-region can be traced back to the Ethio-Eritrea war of 1998-2000 and has to be considered part of its military strategy in a bid to avenge its defeat. To draw Ethiopian attention away from trying to solve the border conflict on the northern front, Eritrea established temporary alliances with Hussein Aidid and AlItahad, and helped build their military capabilities in order to support the enemy of its enemy. ${ }^{21}$

The collapse of the Somali central government exposed the Somalis to deep poverty and insecurity. Thus, many Somalis were forced to move to neighboring countries as refugees. According to the latest report by the U.N. High Commission for Refugees (UNHCR), there are approximately 1.4 million refugees in the Horn of Africa. Almost every country in East Africa and the Horn hosts refugees regardless of its own peace and security situation. Ethiopia hosts almost 116,000 refugees from the Sudan, Somalia and Eritrea."22 This continuous flow of Somalis refugees to the neighboring countries has created another security challenge and concern in the host countries. 
Several field researches indicated that refugee camps located in the region are conducive places for terrorist groups to recruit militants for trans-regional terrorist activities and for illicit small arms movement in the region. Edward Mogire, staff member at the Faculty of Arts and Social Sciences, Kingston University, London, believes that, "In East Africa, terrorism has been linked to the widespread access to illegal weapons. ${ }^{23}$ For example, in January 2007, the Kenyan government arrested 10 foreign Islamist fighters who were trying to cross the border disguised as refugees, and in March 2007, it arrested at least 150 individuals whom it claimed had links to terrorism and then secretly flew them to Somalia and Ethiopia. ${ }^{24}$ Since 1999, Organization of Africa Unity /AU and IGAD have recognized the link between illicit small arms and light weapons and terrorism and ask member states to consider this linkage when developing counter-terrorism measures. ${ }^{25}$ This is seen in the Eastern part of Ethiopia. Ethiopia's eastern and southeastern border with Somalia remains the major source of illegal trade (contraband) and small arms and light weapons trafficking, as well as the main route used by terrorist groups to attack Ethiopia.

Ethiopia's Security Policy and Strategy towards Terrorism in the Horn Ethiopia's national interest is all about building democracy and ensuring peoplecentered development. First and foremost, Ethiopian foreign affairs and security policy and strategy were developed to ensure national security, prosperity and sustainable peace.$^{26}$ Ethiopia is determined to fight terrorism in the Horn because of the repeated targeting by the terrorists groups that affects its security. Second, the Ethiopian government acknowledges that its main security threat is internal and related to domestic poverty and backwardness. However, the country will remain vulnerable to 
internal and external threats including religious fundamentalism and terrorism until sustainable peace is ensured. Third, Ethiopia is known as home for many nations, nationalities and peoples and it has maintained a culture of religious tolerance and peaceful co-existence.

The Federal Democratic Republic of Ethiopia Constitution guarantees freedom of belief and religious equality and separation of state and religion as stated under Article 27 and 11, respectively. Article 27 states "Everyone has the right to freedom of thought, conscience and religion. This right shall include the freedom to hold or to adopt a religion or belief of his choice, and the freedom, either individually or in community with others, and in public or private, to manifest his religion or belief in worship, observance, practice and teaching." ${ }^{27}$ Thus, intolerant religious fundamentalism will affect the constitutional right of Ethiopians and any attempt to spread this type of fundamentalism will spoil the long-standing co-existence of the various religious beliefs in the country. According to Rabasa, "Ethiopian Islam is characterized by patterns of mutual tolerance and symbiosis with Ethiopia's historically dominant Christian culture. According to anthropologist Jon Abbink, although Ethiopians Muslims have in recent years gone through a phase of revivalism and self-assertion, they have remained largely impervious to fundamentalist ideological movements." 28

Ethiopia's security policy and strategy towards Somalia is derived from the basic principles of Ethiopia's foreign relations. The current Ethiopian government believes that any differences and dispute should be resolved through peaceful mechanisms and legal means. Ethiopia also believes that there are numerous historical, cultural and socio-economic links with its neighboring countries, thus tolerance and peaceful means 
should be the primary means to solve differences. Ethiopia's neighbors can be confident that it would not be the source of any threat to their peace, in light of the country's devotion to development and democracy. They will find Ethiopia ready, more than ever before, to address differences based on tolerance, negotiation and the principle of giveand-take. ${ }^{29}$

It is also important to recognize that the lack of peace and stability in any of Ethiopia's neighbors adversely affects Ethiopia's security interests, and impedes efforts to tackle the profound poverty. Ethiopia's security policy and strategy notes that, "As our political and economic vision becomes a reality, our neighbors will see that our vulnerability to external pressure, (far and near) will be reduced, and that, with greater resolution, we would be more capable in preventing conflict." ${ }^{30}$ Therefore, Ethiopia has focused on developing the culture of dealing with differences through discussion and negotiation to avoid violent conflicts while reducing its vulnerability to danger and addressing security threats appropriately. In this regard, the crisis in Somalia has allowed religious extremism to take hold. Somalia has become a haven and conduit for terrorists and extremists. Anti-peace elements are using the country as a base and place of transit in order to threaten Ethiopia's peace. ${ }^{31}$

Consequently, Ethiopia will continue to be exposed to various dangers as long as peace and stability elude Somalia as a whole. In recognition of this, Ethiopia must create the capability to defend itself and foil any attack by forces of extremism, terrorism and other anti-peace elements originating in Somalia. ${ }^{32}$ Finally, Ethiopia should continue to work in cooperation with Somalis, member states of IGAD, and the international community as 
a whole, to stabilize Somalia and neutralize terrorists coming from any part of Somalia to perpetrate attacks against Ethiopia.

International and Regional Community Initiatives to Stabilize Somalia Somalis have a long history of social conflicts based on clan interests and clan identities. UCLA Globalization Research Center-Africa Director and Political Science Professor Edmond J. Keller remarked that, "Social conflicts have historically been largely parochial and based upon clan interests and clan identities." ${ }^{33}$ However, the downfall of Somali's Central government in 199 deepened and exacerbated the situation. Keller observed that, "thousands of innocent Somalis faced the twin threats of war and starvation until the international community, led by UN, decided to intervene for humanitarian reasons in the spring of 1992 . Within a year the humanitarian situation in Somalia had been brought under control, and UN peacekeepers were withdrawn. However, anarchy continued in part of the country." ${ }^{34}$

Over the last two decades, the U.S. government has considered the Horn of Africa a major source of global terrorism. As part of the global war on terrorism, the U.S. government's efforts in the Horn and Yemen have surged to neutralize the worldwide Al-Qaeda networks. Harvard University Intrastate Conflict, Conflict Prevention, and Conflict Resolution Program Director Robert I. Rotberg argued that the U.S. government also recognized that the actual Al-Qaeda operatives and affiliates in the Horn in 2005 were few, but dangerous. ${ }^{35}$ Furthermore, several intelligence reports indicated that several terrorist cells with different levels of cooperation with Al-Qaeda exist in countries such as Yemen, Somalia, Kenya, and beyond into Tanzania and Comoros. ${ }^{36}$ 
The U.S. government expanded its diplomatic, intelligence, law enforcement, and military initiatives to control and neutralize Al-Qaeda's actual and potential pockets in the Horn of Africa and Yemen. According to Rotberg, "The U.S. Central Command's Combined Joint Task Force Horn of Africa (CJTF-HOA) based in Djibouti (and somewhat parallel operations of the Central Intelligence Agency and the Federal Bureau of Investigation) will diminish the likelihood of future Al-Qaeda sponsored attacks on U.S., allied of local targets. ${ }^{37}$ However, Rotberg also argued that U.S. efforts alone might be insufficient to deal with the ongoing threats of Al-Qaeda and homegrown terror in the region.

The current situation in Somalia requires the focus of the international community, the UN, the AU and especially the countries of the Horn. Concerted efforts and concrete steps to strengthen the capabilities of the existing TFG to deny terrorists safe haven in Somalia is the best solution to combating and preventing terrorism, and ensuring a sustainable peace and stability in the sub-region. ${ }^{38}$

The AU and IGAD have taken several measures and steps to counter terrorism in Africa, specifically in the Horn. In this regard, the Convention on the Prevention and Combating of Terrorism adopted by the OAU in October 2001 pushed all countries of the continent to seek regional solutions. "In Somalia, IGAD sought to create an enabling environment for the reconstruction of a collapsed state. In Africa, in particular, subregional organizations such as IGAD have, over the past decade, come to assume a large role in mediating internal conflicts that spill over borders or threaten to do so." ${ }^{39}$ After a subsequent meeting, IGAD finally came out with the document known as the Implementation Plan to Counter Terrorism in the IGAD Region, which was approved by 
the 10th IGAD Summit meeting, held in Kampala on October 24, 2003. Since then, the various IGAD consultations on countering terrorism led to the development of the project known as ICPAT (IGAD Capacity Building Programme against Terrorism) with its central office located in Addis Ababa. ${ }^{40}$

Ethiopia believes the most appropriate mechanism to stabilize Somalia and prevent the spread Islamic fundamentalism, as well as terrorism, in the sub-region is providing assistance to the TFG. As Ethiopian Colonel (retired) Haile Araya noted, Ethiopia "has continued to seek all possible solutions to stabilize the situation in Somalia by supporting the TFG to exercise its powers and duties in the country." ${ }^{41}$ The Ethiopian government has also been building an important relationship with the U.S. government to fight terrorism and to raise up the failed state. To this end, the Ethiopian government has military officers coordinating with the U.S. Counter-Terrorism Combined Joint Task Force-Horn of Africa (CJTF-HOA) stationed at Djibouti and with United States Central Command (USCENTCOM), the U.S. military regional command headquartered in Florida that oversees U.S. counterterrorist operations in Afghanistan and Iraq, as well as in the Horn of Africa. ${ }^{42}$

Factors Adversely Affecting International and Regional Efforts Many argue that the international and regional communities have manifested a reluctance to intervene in Somalia because of the profound breakdown of political, economic and social institutions in Somalia, the persistence of clan-based conflicts between Somalis, and the early experience of their unwelcoming response towards the UN humanitarian mission in Somalia. There is a consensus for preventing and combating terrorism, but concerted regional cooperation is becoming more problematic 
because of the difficulty of arriving at a generally acceptable understanding or perception of the motives of the terrorist activities in the Horn. ${ }^{43}$

The situation is actually worsening because some countries are even supporting local and separatist terrorist groups with the aim of hurting the economic and political stability of their neighboring country. Some countries also may fail to recognize that the instability of one country affects the stability of its neighbors. They may also fear that their involvement in any counter-measures against Islamic extremists in Somalia could attract terrorist attention to their country. Former Ethiopian Prime Minister Meles Zenawi criticized this concern, arguing that, "Many claim that if you respond to the terrorists with force, you spawn terrorism, but if you appease them, you somehow tame them.." ${ }^{\prime 4}$ The challenge is to overcome biases against action through close, recurrent dialogue, discussions, and diplomatic outreach.

\section{Conclusion and Recommendations}

East Africa has been unstable for the last two decades. This due to the collapse of the Somali central government coupled with transnational terrorism which has created a more conducive environment for the existence of extremists, terrorist groups and Al-Qaeda cells in the region. Ethiopia experiences significant security challenges due to the presence of Somali terrorists and their local terrorist group affiliates. Since the mid 1990s, Somalia terrorist groups like AIAI and ICU, combined with indigenous terrorist groups like OLF and ONLF, have attacked Ethiopia several times. Direct terrorist attacks from Somalis and local terrorists, proxy attacks from the Eritrean government, illegal trade, proliferation of small arms, and human trafficking are the major security challenges in the region. 
Ethiopia has taken pre-emptive military measures to repel the immediate security threat posed by the combined forces of Somali and local terrorist groups. Ethiopia and the other IGAD countries have also continued to support the stabilization of Somalia since the formation of the TFG. Ethiopia's response towards Somalis and Somaliabased terrorists is based on the fundamental principles of Ethiopia's foreign affairs and security policy and strategy, i.e. tolerance, peaceful resolution of differences, and protecting Ethiopia's national interests. Thus, Ethiopia's political, diplomatic and military initiatives towards the Horn and Somalia paved the way to build up the failed state and to fight terrorists.

An encouraging situation has finally emerged in Somalia after two decades of senseless inter-clan war. However, Somalia is still far from its goals of building a strong central government and defeating terrorism. The prevailing situation in Somalia requires more coordinated and integrated endeavors by all stakeholders, and especially between the United States and the Horn countries. The following recommendations are provided to help sustain Ethiopia's national security, stabilize Somalia, and support counter terrorism in the Horn.

First, the Horn countries should promote regional security cooperation through the continued exchange of intelligence, conflict warning, and prevention mechanisms for common security threats. This includes strengthening existing regional institutions such as IGAD and the East Africa Standby Brigade. Lack of resources and capacity are two of the most important obstacles to greater regional security cooperation. Countries that agree to cooperate will increase their likelihood of receiving assistance from the U.S. and European Union to meet these threats. 
Second, the Horn counties should focus on poverty reduction programs. Poverty is the main source of conflict and insecurity in the Horn, specifically in the border areas. Therefore, the Horn countries should emphasize poverty reduction programs in their respective countries, as well as develop and implement regional poverty reduction initiatives such as designing and implementing common infrastructure projects to connect the sub-region through roads, railways and power.

Third, the Horn countries should expand and organize their diplomatic, political and security support to strengthen the TFG and its security forces as well as to encourage Somalis to settle their differences through peaceful means. The Horn countries' efforts to counter terrorism in the Horn will not be fruitful without the existence of a strong Somali central government.

Fourth, the U.S and Ethiopia should strengthen bilateral military-to-military relations. The U.S. and Ethiopia need to establish clear, common objectives to counter terrorism in the region. The U.S. government would benefit by working more closely with Ethiopia and Ethiopia could benefit from U.S. military and intelligence capabilities, and capacity building programs, in their joint fight against terrorism. This cooperation could also encompass a range of activities, such as enhancing the capabilities of Ethiopian officers and conducting joint exercises to improve the operational capabilities of the Ethiopian army.

\section{Endnotes}

${ }^{1}$ Gebru Tareke, The Ethiopia-Somalia War of 1977 Revisited, (The International Journal of African Historical Studies, Vol.33, No.3, 2000), 635.

${ }^{2}$ Ethiopia, Foreign and National Security Policy and Strategy, 73.

${ }^{3}$ Tareke, The Ethiopia-Somalia War of 1977 Revisited, 663. 
${ }^{4}$ Ibid., 73.

${ }^{5}$ Angel Rabasa, Radical Islam in East Africa: Rand Corporation (United States Air Force 2009, Volume MG-782-AF), 39.

${ }^{6}$ Ibid., 39.

${ }^{7}$ Marc Sageman, Understanding Terror Networks, Philadelphia: (University of Pennsylvania press, 2004), 36.

${ }^{8}$ Ibid., 36.

9 James Phillips, Somalia and Al-Qaeda: Implications for the War on Terrorism, http://www.heritage.org/Research/HomelandDefense/BG1526.cfm (accessed Oct. 25, 2012).

${ }^{10}$ Haile Araya, Terrorist Activities Challenging the Horn of Africa, The 2nd Annual Combating and Preventing Terrorism in Africa, Pretoria (South Africa, 2007), 15-17.

${ }^{11}$ Joseph S. Truman, Communicating Terror: The Rhetorical Dimensions of Terrorism, Second Edition (Sage Publications, Inc 2010), 5.

${ }^{12}$ Ibid., 6.

${ }^{13}$ Ibid., 7.

${ }^{14}$ The Federal Democratic Republic of Ethiopia, Anti-Terrorism Law, (Proc.No.652/2009), Addis Ababa, 2009.

${ }^{15}$ Andre Le Sage, African Counterterrorism Cooperation, Assessing Regional and Sub-regional Initiatives (Africa Center for Strategic Studies, National Defense University, Washington, D.C, 2007), 1.

${ }^{16}$ United States Institute of Peace, "Terrorism in the Horn of Africa," Special Report 113, (1200 17thStreet NW. Washington, D.C 20036, 2004), 2.

${ }^{17}$ Robert I. Rotberg, "Battling Terrorism in the Horn of Africa," World Peace Foundation Cambridge, Massachusetts and Brookings Institution press, (Washington, D.C, 2005), 94.

${ }^{18}$ Ibid., p.109

${ }^{19}$ United Nations, Security Council Resolution (December 2011), http://www.securitycouncilreport.org/site /c.glKWLeMTIsG/b.2713951/ (accessed Oct. 25, 2012) 
${ }^{20}$ Temesgen Gidey, Ethiopian-Eritrean Conflict: Security Implications for the Horn of Africa, Strategy Research Project (Carlisle Barracks, PA: U.S. Army War College 2012), 14.

${ }^{21}$ Roland Marchal, Islamic Political Dynamics in the Somalia Civil War Before and After September 11, in Alex de Waal, (Ed). Islamism and its Enemies in the Horn of Africa, Bloomington and Indianapolis (Indiana University Press, 2004), 138.

${ }^{22}$ Dorina A. Bekoe, East Africa and the Horn Confronting Challenges to Good Governance (International Peace Academy Occasional Paper, 2006), 37.

${ }^{23}$ Edward Mogire, Victims as Security Threats: Refugee Impact on Host State Security in Africa (Kingston University, UK, ASHGATE 2011), 141.

${ }^{24}$ Ibid., 137.

${ }^{25}$ Ibid., 141.

${ }^{26}$ Ethiopia, Foreign and National Security Policy and Strategy, 1-6.

${ }^{27}$ Constitution of the Federal Democratic Republic of Ethiopia, Addis Ababa, 1995.

${ }^{28}$ Rabasa, Radical Islam in East Africa, 39.

${ }^{29}$ Ethiopia, Foreign and National Security Policy and Strategy, 1-6.

${ }^{30}$ Ibid.,1-6.

${ }^{31}$ Ibid., 1-6.

${ }^{32}$ Ibid., 1-6.

${ }^{33}$ Edmond J.Keller, Understanding Conflicts in the Horn of Africa, in Chandra Lekha Sriram and Zoe Nielsen.,eds., Exploring Sub-regional Conflict: Opportunities for Conflict Prevention (International Peace Academy, 2004), 30.

${ }^{34}$ lbid., 34.

${ }^{35}$ Robert I. Rotberg, Battling Terrorism in the Horn of Africa, 2.

${ }^{36}$ Ibid., 2.

${ }^{37}$ Ibid., 2.

${ }^{38}$ Haile Araya, Terrorist Activities Challenging the Horn of Africa, 21.

${ }^{39}$ Edmond J.Keller, Understanding Conflicts in the Horn of Africa, 37. 
${ }^{40}$ Haile Araya, Terrorist Activities Challenging the Horn of Africa, 20.

${ }^{41}$ Ibid., 20.

${ }^{42} \mathrm{Jim}$ Fisher-Thompson, African Cooperation Growing on Anti-Terrorism, in Haile Araya, Terrorist Activities Challenging the Horn of Africa, The 2nd Annual Combating and Preventing Terrorism in Africa, Pretoria (South Africa, 2007), 15-17.

${ }^{43}$ lbid., 21.

${ }^{44}$ Meles Zenawi, Interview for Washington Post (Dec 14, 2006), in Haile Araya, Terrorist Activities Challenging the Horn of Africa, The 2nd Annual Combating and Preventing Terrorism in Africa, Pretoria (South Africa, 2007), 15-17. 
